\title{
Cephalic and Facial Indices Among Kosovo-Albanian Population
}

\author{
Índices Cefálico y Facial en la Población Kosovar-Albanesa
}

\author{
Gloria Staka; Metush Disha \& Fatmir Dragidella
}

STAKA, G.; DISHA, M. \& DRAGIDELLA, F. Cephalic and facial indices among Kosovo-Albanian Pupulation. Int. J. Morphol., 31(2):468-472, 2013.

SUMMARY: Cephalic and facial indices are used to estimate the racial and sex differences. This study was carried out to establish standards for craniofacial variables and distribution of cephalic and facial indices in Kosovo - Albanian population. The study population consisted of 204 dental students (101 males and 103 females, aged 18 to 30). Four basic craniofacial variables (head length, head breadth, morphological face height and face breadth) were measured to obtained cephalic and facial indices. All measured craniofacial variables are considerably higher in males than in females $(\mathrm{p}<0.0001)$. In the Kosovo - Albanian population brachycephalic type of head $(44.61 \%)$ and hyperleptoprosopic type of face $(63.34 \%)$ prevail.

KEY WORDS: Cephalic index; Facial index; Brachycephalic; Hyperleptoprosopic; Kosovo-Albanian Population.

\section{INTRODUCTION}

Human physical variability has been a subject of great interest for the scientists for a very long time and anthropometry evolved as a standard scientific technique for measuring human body dimensions (Eickstedt,1926). Human body dimensions are affected by ecological, biological, geographical, racial, sex, age and nutritional factors (Golalipour et al., 2001; Rajlakshmi et al., 2001; Radovic et al., 2000; Tulli et al., 1995; Okupe et al., 1984).

Anthropometric studies are conducted on the age, sex and racial/ethnic groups in certain geographical zones (Williams et al., 1995; del Sol, 2005; Shah \& Jadhav, 2004; Golalipour et al., 2007). Anthropometric measurements are important for studying variation in human population. (Hardlika,1939; Montague,1960; Comas, 1960). Variation is one of the most important phenomenon occurring human populations on this globe (Pandey, 2006) Anthropometric variation has been a point of study not only in physical anthropology, but other fields such as genetics, anatomy, dentistry and for industrial purposes (Roberts, 1956 \& Kohn, 1991).

Cephalometry is one of important branches of anthropology in which the dimensions of head and face can be determined. The shape of the head and face depend on many factors, such as racial and ethnical affiliation, climate, surroundings, socio-economic, nutritional and genetics influences (Radovic et al., 2000). Measurement of the craniofacial variables is important for studies of human growth, population variation and clinical treatment.

Cephalic and facial indices are important parameters that are useful in anthropological studies for ascertaining the variation between different race, ethnic groups and sex (Williams et al., 1955).

This study was aimed to establish standards for craniofacial variables of Kosovo - Albanian population and distribution of cephalic and facial indices.

\section{MATERIAL AND METHOD}

The study sample consisted of 204 subjects (101 males and 103 females) from the Dental School, Medical Faculty, University of Prishtina, Prishtina (Republic of Kosovo). The age of the subjects ranged from 18-30 years. Subjects who met the following criteria were included in this study: all subjects were native Kosovo-Albanian, normal craniofacial configuration, no know history of craniofacial surgery, trauma or craniofacial abnormalities in the family. We obtained permission to conduct the study from the authorities of the selected faculty and participating students were properly briefed on the purpose and the procedure of the research. Only verbally consenting volunteers were sampled for the study. 
Four basic craniofacial variables (head length, head breadth, morphological face height and face breadth) were taken on each subject following the techniques of Martin \& Saller (1957) and designated as follows:

1. Head length (glabella-opisthocranion; g-op)

2. Head breadth (euryon-euryon; eu-eu)

3. Morphological face height (nasion-gnathion; $\mathrm{n}-\mathrm{gn}$ )

4. Face breadth (zygion-zygion; zy-zy)

Craniofacial variables were measured using standard anthropometry instruments with great accuracy (GPM, anthropological instruments, Siber-Hegner \& Co.AG and electronic digital caliper, Boss Hamburg-Germany). To reduce technical error of the measurements, each measurement was taken thrice and average taken.

On the base of the mentioned measurements the cephalic index $(\mathrm{CI})$ and facial index (FI) was calculated according to Martin \& Saller (1957) with following formulae:

$$
\begin{aligned}
& \mathrm{CI}=(\text { eu-eu } / \text { g-op }) \times 100 \\
& \mathrm{FI}=(\text { n-gn } / \text { zy-zy }) \times 100
\end{aligned}
$$

The obtained data were subjected to statistical analysis. Basic descriptive statistics, independent t-test, distribution of cephalic and facial types were calculated using computerized statistical analysis software - SPSS (Statistical Package for Social Sciences) version 11.0. The p-value of $<$ 0.05 was considered statistically significant.

\section{RESULTS}

The results of the study were presented in tabular form. Basic descriptive statistics and differences between males and females in measured craniofacial variables are shown in Table I. The mean head length, head breadth, morphological face height and face breadth in male subjects was significantly higher than those in female subjects $(\mathrm{p}<0.0001)$.

Descriptive statistics showed minimum and maximum cephalic index to be 73.17-92.12 in males and $76.32-94.51$ in females. Mean cephalic index were 84.37士 3.56 and $84.80 \pm 3.80$ for males and females respectively, and the difference is statistically insignificant ( $p>0.05)$. The mean cephalic index of $84.37 \pm 3.56$ and $84.80 \pm 3.80$ fall under the brachycephalic type of head according to Martin \& Saller (1957) (Table II).

Descriptive statistics showed minimum and maximum facial index to be $83.00-114.47$ in males and $78.44-110.32$ in females. Mean facial index were $95.60 \pm$ 6.67 and $93.41 \pm 6.04$ for males and females respectively, and the difference is statistically significant $(\mathrm{p}<0.05)$, ( Table III). The mean facial index of $95.60 \pm 6.67$ and $93.41 \pm 6.04$ fall under hyperleptoprosopic type of face.

According to the cephalic index (CI) in KosovoAlbanian population $44.61 \%$ were brachycephalic, $34.80 \%$ hyperbrachycephalic, $17.65 \%$ mesocephalic, $1.47 \%$ ultrabrachycephalic and 1.47 dolichocephalic (Table IV).

Table I Basic descriptive statistic of craniofacial variables.

\begin{tabular}{lcccccccc}
\hline Variable & Male & Mean \pm SD & CV & Female & Mean \pm SD & CV & t-value & p-value \\
\hline gl-op & 101 & $187.30 \pm 7.23$ & 3.86 & 103 & $176.85 \pm 5.37$ & 3.04 & 11.73 & $\mathrm{p}<0.0001$ \\
eu-eu & 101 & $157.86 \pm 5.58$ & 3.53 & 103 & $149.85 \pm .563$ & 3.76 & 10.25 & $\mathrm{p}<0.0001$ \\
zy-zy & 101 & $131.93 \pm 6.72$ & 5.10 & 103 & $123.93 \pm 5.59$ & 4.51 & 9.25 & $\mathrm{p}<0.0001$ \\
n-gn & 101 & $125.82 \pm 6.37$ & 5.06 & 103 & $115.57 \pm 5.00$ & 4.33 & 12.79 & $\mathrm{p}<0.0001$ \\
\hline
\end{tabular}

$\mathrm{p}<0.0001 *$ All measurements are given in millimeters

Table II. Descriptive statistics of cephalic index among Kosovo- Albanian population

\begin{tabular}{lllllll}
\hline Sex & $\mathrm{N}$ & Mean $\pm \mathrm{SD}$ & Range & $95 \%$ CI & CV\% & $\mathrm{p}$-value \\
\hline Male & 101 & $84.37 \pm 3.56$ & $73.17-92.12$ & $83.68-85.06$ & 4.22 & $\mathrm{t}=0.343$ \\
Female & 103 & $84.80 \pm 3.80$ & $76.32-94.51$ & $84.06-85.53$ & 4.48 & $\mathrm{p}>0.05$ \\
Total & 204 & $84.59 \pm 3.68$ & $73.17-94.51$ & $83.87-85.30$ & 4.35 & \\
\hline
\end{tabular}

Table III. Descriptive statistics of facial index among Kosovo- Albanian population

\begin{tabular}{lcccccc}
\hline Sex & $\mathrm{N}$ & Mean \pm SD & Range & $95 \%$ CI & CV\% & p-value \\
\hline Male & 101 & $95.60 \pm 6.67$ & $83.00-114.47$ & $94.30-96.89$ & 6.98 & $\mathrm{t}=2.459$ \\
Female & 103 & $93.41 \pm 6.04$ & $78.44-110.32$ & $92.24-94.58$ & 6.46 & $\mathrm{p}<0.05$ \\
Total & 204 & $94.49 \pm 6.44$ & $78.44-114.47$ & $93.25-95.74$ & 6.81 &
\end{tabular}


Table IV. Distribution of cephalic index among Kosovo-Albanian population (Martin \& Saller scale).

\begin{tabular}{lccc}
\hline Cephalic index & $\begin{array}{c}\text { Male } \\
\mathrm{n}(\%)\end{array}$ & $\begin{array}{c}\text { Female } \\
\mathrm{n}(\%)\end{array}$ & $\begin{array}{c}\text { Total } \\
\mathrm{n}(\%)\end{array}$ \\
\hline Dolichocephalic & $1(0.99)$ & $2(1.94)$ & $3(1.47)$ \\
Mesocephalic & $12(11.88)$ & $24(23.30)$ & $36(17.65)$ \\
Brachycephalic & $49(48.51)$ & $42(40.78)$ & $91(44.61)$ \\
Hyperbrachycephalic & $38(37.62)$ & $33(32.04)$ & $71(34.80)$ \\
Ultrabrachycephalic & $1(0.99)$ & $2(1.94)$ & $3(1.47)$ \\
Total & $101(49.51)$ & $103(50.49)$ & $204(100.00)$ \\
\hline
\end{tabular}

According to the facial index (FI) hyperleptoprosopia $63.24 \%$ is the most frequent feature in the Kosovo-Albanian population, followed by leptoprosopia $26.96 \%$, mesoprosopia $7.35 \%$ and euryprosopia $2.45 \%$ (Table V).

Table V. Distribution of facial index among Kosovo-Albanian population (Martin \&-Saller scale)

\begin{tabular}{lccc}
\hline Facial index & $\begin{array}{c}\text { Male } \\
\mathrm{n}(\%)\end{array}$ & $\begin{array}{c}\text { Female } \\
\mathrm{n}(\%)\end{array}$ & $\begin{array}{c}\text { Total } \\
\mathrm{n}(\%)\end{array}$ \\
\hline Hypereuriprosopic & - & - & - \\
Euryprosopic & $4(3.96)$ & $1(0.97)$ & $5(2.45)$ \\
Mesoprosopic & $8(7.92)$ & $7(6.80)$ & $15(7.35)$ \\
Leptoprosopic & $31(30.69)$ & $24(23.30)$ & $55(26.96)$ \\
Hyperleptoprosopic & $58(57.43)$ & $71(68.93)$ & $129(63.24)$ \\
Total & $101(49.51)$ & $103(50.49)$ & $204(100.00)$ \\
\hline
\end{tabular}

\section{DISCUSSION}

This study focused on the craniofacial anthropometrical measurements of healthy Kosovo-Albanian population. Our research was oriented to identifying the average craniofacial variables and distribution of cephalic and facial indices.

The obtained data were separated according to sex. Sexual dimorphism was found to be statistically significant in all measured craniofacial variables $\mathrm{p}<0.0001$ (Table I). Many authors have noticed significant differences in craniofacial variables among sex (Savara \& Singh, 1968; Woodside \& Linder-Aronson,1979; Foley \& Mamandras, 1992; Ingerslev \& Solow, 1975; Njemirovskij et al., 2000; Vidovic', 1979; Nagle et al., 2005).

In present study mean cephalic index of male subjects was 84.37. while in female subjects was 84.80. Similar result of cephalic index in Kosovo-Albanian population were found in studies of Pittard (1916) and Rexhepi \& Meka (2008).

The mean cephalic index observed in this study (84.59) was higher than those observed for the Turkman: 80.4 (Golalipour et al.,
2007), Indians: 80.42 (Shah \& Jadhav, 2004), Mapuche individuals in Chile: 80.42 (del Sol), European people in Mediterranean area: 81.19, North Europeans:79.72, Chileans: 81.51 (García \& Lips, 1986a,b), Iranians:75 (Abolhasanzadeh \& Farahani, 2003), Croatian:79.37. (Buteric'Tomljanovic' et al., 2004). Cephalic index in study population was similar with native Fars: 84.8 (Golalipour, 2006) and lower than Japanese: 87 (Nakashima,1996).

The mean facial index among KosovoAlbanian Population (94.49) was higher than in the North Iranian Fars (Jahanshahi et al., 2008), North Iran Turkman (Jahanshahi et al., 2008), Nigeran Tangale (Maina et al., 2012). Facial index in study population was lower than Nigerian/ Fulani, Nigeria/Tera, (Maina et al., 2012) and Northeaster Nigerian (Raji et al., 2010). Facial index in study population was similar with Croatian of south Dalmatian region: 93.37 (Njemirovskij et al., 2000).

In our study, dominant head type of Kosovo - Albanian population was brachycephalic (44.61\%) followed by hyperbrachycephalic $(34.80 \%)$. According to the facial index, dominant face type was hyperleptoprosopia (63.24\%).

Cephalic and facial indices from our study is agreed by studies of Rexhepi \& Meka (2008), Behluli (1987), Dhima (1985), Gluck (1897).

Anthropological studies have determinated that people from Africa, India, Australia, central part of Europe and north America are dolicocephalic. The head type of people in Pacific Ocean are brachycephalic type, while Middle East, Russia and central part of Europe are mesocephalic type (Chamela,1997; Golalipour et al., 2003). Variation in cephalic indices between and within populations have bene attributed to a complex interaction of genetic and environmental factors (Kasai et al.,1993). Interestingly, even dietary habits have been shown to influence the craniofacial of a population (Kasai et al.,1993).

The values of all measured craniofacial variables can serve as standards for defined population group. Craniofacial variables are considerably higher in males then in females. In the Kosovo - Albanian population the mean value of the cephalic index (CI) is 84.59 with 
insignificant differences in relation to sex, indicating the prevalence of brachycephalia. The mean value of the facial index (FI) is 94.49 with significant differences in relation to sex, indicating the prevalence of hyperleptoprosopia.

The results of this study will be useful in anthropology, genetics, forensic medicine and can be used as local standards for diagnostic and anthropometric evaluation.

ACKNOWLEDGMENTS. We wish to thank students of the Dental School, Medical Faculty, University of Prishtina, for participation, patience and support.

STAKA, G.; DISHA, M. \& DRAGIDELLA, F. Índices cefálico y facial en la población Kosovar-Albanesa. Int. J. Morphol., 31(2):468472, 2013.

RESUMEN: Los índices cefálicos y faciales se utilizan para estimar las diferencias raciales y de sexo. Este estudio se llevó a cabo para establecer estándares para las variables y la distribución de los índices cefálicos y faciales en la población de KosovoAlbanesa. Se examinaron 204 estudiantes de odontología (101 hombres y 103 mujeres entre 18 y 30 años). Se midieron cuatro variables craneofaciales básicas (longitud de la cabeza, ancho de la cabeza, altura facial morfológica y ancho facial) para obtener los índices cefálicos y faciales. Todas las variables medidas craneofaciales fueron considerablemente más altas en los hombres que en las mujeres ( $\mathrm{p}$ $<0,0001)$. En la población Kosovo-Albania predomina la braquiocefalia $(44,61 \%)$ y la hiperleptoprosopía $(63,34 \%)$.

PALABRAS CLAVE: Índice cefálico; Índice facial; Braquicéfalos; Hiperleptoprosópicos; Población Kosovo-albanesa.

\section{REFERENCES}

Abolhasanzadeh, A. \& Farahani, M.R. Standarded international classification of head shape of 22-24 years old Teheran. $J$. Research in Medicine., 26(4):281-5, 2003.

Behluli, I. Biometrijska analiza morfolos `kih i fiziolos``kih svojstva u odraslih osoba s obzirom na funkciju respiratornog sistema. $\mathrm{PhD}$ dissertation, University of Pris`tina, Kosovo, 1987.

Buteric'-Tomljanovic', A.; Ristic', S.; Brajenovic'-Milic', B.; Ostojic', S.; Gombac, E. \& Kapovic', M. Secular change in body height and cephalic index of Croatian medical students (University of Rijeka). Am. J. Phys. Anthropol., 123 (1):91-9, 2004.

Chamella, M. Biological Anthropology. Translated to Persian (Fars) by Nadri A. $1^{\text {st }}$ Ed. Teheran, Gostar Publisher, 1997.

Comas, J. Mannual of Physical Anthropology. Charles C Thomas, Illinois (USA), 1960.

Dhima, D.H.A. Gjutmimet antropologjike për shqiptarët. Tirana, p 28/9. 106/12,126/8, 1985.

Del Sol, M. Cephalic index in a group of Mapuche individuals in the IX Region of Chile. Int. J. Morphol., 23 (3):241-6, 2005.

Eicksted, E.V. The race and types of the western Himalayas. Man in India, 6:237, 1926.

Foley, T. F.; Antonios,H. \& Mamandras A.H. Facial growth in females 14-20 years of age. Am. J. Orthod. Dentofacial. Orthop., 101(3):248-54, 1992.
García, H. F. \& Lips, M. W. Contribucion al studio del indice cefálico en chilenos. An. Anat. Norm., 4:120-3,1986a.

García, H. F .\& Lips, M. W. Variaciones del índice cefálico según ascendencia. An. Anat. Norm., 4:117- 9, 1986b.

Glück, L. Zur physischen anthropologie der Albanesen. Wissenschaften und Mitteilungen aus Bosnien und der Hercegovina, 5:365-402, 1897.

Golalipour, M.J.; Haidari, K.; Jahanshahi, M. \& Frahani, M.R. The shapes of head and face in normal male newborns in southeast of Caspian Sea (Iran-Gorgan). J. Anat. Soc. India., 52:28$31,2003$.

Golalipour, M. J. The variation of head shape in 17-20 years old native Fars male in Gorgan-North of Iran. Int. J. Morphol., 24:187-90, 2006.

Golalipour, M. J.; Jahanshahi, M. \& Haidari,K. Morphological evaluation of head in Turkman males in Gorgian-North of Iran. Int. J. Morphol., 25(1):99-102, 2007.

Hardlika, A. Practical Anthropometry. Philadelphia. 1937.

Ingerslev, C, H. \& Solow, B. Sex difference in craniofacial morphology. Acta Odontol. Scan., 33:85-94, 1975.

Jahanshahi, M.; Golalipour, M. J. \& Heidari, K. The effect of ethnicity on facial anthropometry in North Iran. Singapure. Med. J., 49:940-3, 2008. 
Kasai, K.; Richard, L.C. \& Brown, T. Comparative study of craniofacial morphology in Japonese and Australian aboriginal population. Hum. Biol., 65:821-34, 1993.

Kohn, L.A.P. The role of genetics in craniofacial morphology and growth. Annu. Rev. Anthropol., 20:261-87, 1991.

Maina, M. B.; Mahdi, O. \& Kalayi, G. G. Craniofacial forms among three dominant ethnic groups of Gombe State, Nigeria. Int. J. Morphol., 30(1): 211-16, 2012.

Montague, Ashley M. F. An Introduction to Physical Anthropology. Springfield, Illinois, (USA), 1960.

Nagle, E.; Teibe, U. \& Kapoka, D. Craniofacial anthropometry in a group of healthy Latvian residents. Acta Medica Lituanica., 12 (1): 47-53, 2005.

Nakashima, T. Brachycephalization in the head form of school girls in North Kyushu. J. UOEH., 8:411-4, 1986.

Njemirovskij, V.; Radovic', Z.; Komar, D.; Lazic', B. \& Kuna, T. Distribution of craniofacial variables in South Dalmatian and Middle Croatian populations. Coll. Antropol., 1:49-56, 2000.

Okupe, R.F.; Cooker, O.O. \& Gbajumo, S.A. Assessment of fetal biparital diameter during normal pregnancy by ultrasound in Nigerian women. British. J. Obstet. Gynecol., 99:629-32, 1984.

Pandey, A.K. Cephalo-facial variation among Onges. Anthropol., 8(4):245-9, 2006.

Pittard, E. Les peuples des Balkans. First Edition. Attinger frères. Paris, p. 84-5. 1916.

Radovic, Z.; Muretic , Z.; Nemirovskij, V. \& Gazi-Coklica, V. Craniofacial variations in a South Dalmatian Population. Acta. Stomatol. Croat., 34 (4):399-403, 2000.

Raji, J. M.; Garba, S. H.; Numan, A. I.; Waziri, M. A. \& Maina, M. B. Morfological evaluation of head and face shapes in North Eastern Nigerian population. Aust. J. Basic. Appl. Sci., 4:333841, 2010.

Rajlakshmi, C. H.; Shyamo Singh, M.; Bidhumukhi, T. H. \& Chandramani. Singh, M. Cephalic index of foetuses of Manipuri population - A Baseline study. J. Anat. Soc. India., 50(1):13-6, 2001.

Rexhepi, A. \& Meka, V. Craniofacial morphological characteristics of Albanian Kosova population. Int. J. Morphol., 26 (4):93540, 2008.

Roberts, D.F. Industrial applications of body measurements. Am. Anthropol., 58:526-35, 1956.

Savara, B. S.\& Singh I. J. Norms of size and annual increments of seven anatomical measures of maxillae in boys from three to sixteen years of age. Angle Orthod., 38(2): 104-20, 1968.
Shah, G. V. \& Jadhav, H. R. The study of cephalic index in the students of Gujarat. J. Anat. Soc. India., 53(1):25-6, 2004.

Tuli, A.; Choudhry, R.; Agarwal, S.; Anand, C. \& Gary, H. Correlation between craniofacial dimensions and foetal age. J. Anat.Soc. India., 44 (1):1-12, 1995.

Vidovic', Z. Rezultati antropometriskih ispitivanja orofacialnog sistema kod osoba sa pravilnom okluzijom u periodu stalnihzuba. Stomat. Glas. Srb., 1:39-46, 1979.

Woodside, D. G. \& Linder-Aronson, S. The channelization of upper and lower anterior face heights compared to population standard in males between 6 to 20 years. Europ. J. Orthod. 1(1):2540, 1979.

Williams, P.; Dyson, M.; Dussak, J. E.; Bannister. L. H.; Berry, M. M.; Collins, P.\& Fergson, M. W. J. Gray's Anatomy. In: Skeletal system. $38^{\text {th }}$ Ed. Elbs with Churchill Livingston. London, 1995. pp. 607-12.

Correspondence to:

Dr. Gloria Staka

Assistant Professor

Dental School

Faculty of Medicine

University of Prishtina

Prishtina

REPUBLIC OF KOSOVO

Email: gstaka@yahoo.co.uk

Received: 10-10-2012

Accepted: 29-01-2013 